\title{
Learning and Assessment Practices of Doctoral Studies of Developing and Developed Countries: A Case Study of Doctoral Studies in Bangladesh
}

\author{
Ahabab Chowdhury \\ University of Wollongong, Wollongong, Australia
}

orco 1998@yahoo.com

\begin{abstract}
Since the inception of the information age, employees in both developed and developing countries have become 'knowledge workers'. In their work, knowledge workers apply knowledge as well as skills, while labour is provided by tools and machines (Maclean \& Wilson, 2009). Contemporary employees require appropriate knowledge to be able to share this knowledge through their advanced skills. Hence, an advanced university education is pivotal. However, Jones's (2013) study indicates a paucity of research into the learning and assessment of $\mathrm{PhD}$ programmes (p. 6). As a result, many $\mathrm{PhD}$ graduates - especially those from developing countries - are finding themselves unemployed. If this continues, fewer skilled and knowledgeable $\mathrm{PhD}$ graduatesin other words, successful researchers-will qualify, particularly in developing countries. Hence, this paper aims to investigate why the existing learning and assessment practices of doctoral studies in Bangladesh need to be redesigned. The paper is significant because it comprises the initial research prior to more conclusive research into the learning and assessment practices of doctoral studies in Bangladesh. This paper will help to close a knowledge gap by providing significant insights into the area of learning and assessment practices of $\mathrm{PhD}$ programmes in developing countries.
\end{abstract}

Keywords: Doctoral studies, PhD programs, Learning and Assessment Practices, Developed Countries, Developing Countries, PhD Models, Globalisation, Brain Drain, Multidisciplinary, Research and Development.

\section{Introduction}

Since the inception of the information age, employees in both developed and developing countries have become 'knowledge workers'. In their work, knowledge workers apply knowledge as well as skills, while labour is provided by tools and machines (Maclean \& Wilson, 2009). Con-

Material published as part of this publication, either on-line or in print, is copyrighted by the Informing Science Institute. Permission to make digital or paper copy of part or all of these works for personal or classroom use is granted without fee provided that the copies are not made or distributed for profit or commercial advantage AND that copies 1) bear this notice in full and 2) give the full citation on the first page. It is permissible to abstract these works so long as credit is given. To copy in all other cases or to republish or to post on a server or to redistribute to lists requires specific permission and payment of a fee. Contact Publisher@InformingScience.org to request redistribution permission. temporary employees require appropriate knowledge to be able to share this knowledge through their advanced skills. Hence, an advanced university education is pivotal. However, the education of knowledge workers does not end with a tertiary degree; learning is lifelong. The journey of lifelong learning has four phases: 1) knowing where we are now; 2) knowing where we need to be; 3) knowing how to get there; and 
4) knowing that we have got there (Tovey \& Lawlor, 2008). Therefore, an individual should know what learning processes they need to embrace and, most importantly, the assessments they need to complete to become qualified for the next stage in their learning.

Recent studies show that the nature of doctoral studies has changed remarkably. The drivers of change are competition, consumerism, and corporatism (Naidoo \& Jamienson, 2007, p. 363). Universities offering Doctor of Philosophy $(\mathrm{PhD})$ programmes are now reviewing these changes both locally and globally. One of the emerging issues is the learning and assessment practices of traditional PhD models. Jones's (2013) study indicates a paucity of research into the learning and assessment of $\mathrm{PhD}$ programmes (p. 6). As a result, many $\mathrm{PhD}$ graduates - especially those from developing countries - are finding themselves unemployed. If this continues, fewer skilled and knowledgeable $\mathrm{PhD}$ graduates - in other words, successful researchers - will qualify, particularly in developing countries.

This discussion paper is exploratory. It aims to investigate why the existing learning and assessment practices of doctoral studies in Bangladesh need to be redesigned. The paper is significant because it comprises the initial research prior to more conclusive research into the learning and assessment practices of doctoral studies in Bangladesh. This paper will help to close a knowledge gap by providing significant insights into the area of learning and assessment practices of $\mathrm{PhD}$ programmes in developing countries.

To explore the present learning and assessment practices of PhD programmes in Bangladesh, this paper will first conduct a critical evaluation of the extant literature on the doctoral studies of developed countries. The study seeks to address some of the noteworthy research findings that stipulate ongoing practices as well as the shortcomings of the traditional academic $\mathrm{PhD}$ models of developed countries. Next, the paper will discuss some major challenges faced by developing countries that offer PhD programmes. Further, by discussing doctoral studies in developing countries, the paper will attempt to introduce some issues of concern, such as China, Singapore, and Africa. Then, Bangladesh - as one representative of a developing country — will be used as a case study.

The initial discussion aims to identify the overall enrolment growth of higher education programmes, including doctoral studies in Bangladesh. The paper will review three different Bangladeshi universities to explore their current learning and assessment processes for $\mathrm{PhD}$ programmes. At the end of this section, the paper will conduct a comparative analysis that will present some of the common practices as well as the differences in terms of learning and assessment practices of doctoral studies in developing and developed countries. Next, the paper will attempt to explain the theoretical framework by incorporating four different theories: 1) Bozeman, Dietz and Gaughan's (2001) theory of social and technical human capital; 2) Levine's (2007) nine-point template; 3) Lovitts's (2005) study; and 4) Leech's (2012) model. The study will examine the strengths and weaknesses of each of these theories in conjunction with the issues identified in the learning and assessment practices of doctoral studies in developed and developing countries. The paper will conclude by making some recommendations that will shed light on the present issues of concern in relation to doctoral studies in Bangladesh. One of the main objectives of this study is to extend benefits to $\mathrm{PhD}$ providers, candidates, supervisors, and examiners, not only in Bangladesh but also around the world.

\section{Research Method}

As this study is exploratory, it will conduct secondary research by reviewing the extant literature and theories pertinent to the main theme. The relevant literature was searched using databases including Proquest, Scopus and Eric, as well as the institutional websites of the selected universities in Bangladesh. 


\section{Literature Review}

\section{A Critical Evaluation of Doctoral Studies: Developed Countries}

With the inception of the information age, one of the fundamental challenges for both developed and developing countries is to strike a balance between the changing needs of the knowledge economy and the skills required to conduct research and development (R\&D) to meet these needs. Kehm's (2004) research into doctoral studies in some developed countries indicates that the new workforce of the emerging knowledge economy needs to possess research skills so that society can flourish through innovation (p. 293). Kehm's study focuses on the challenges faced by developed countries including Austria, France, Germany, Italy, the Netherlands, Poland, Sweden, the United Kingdom (UK), and the United States (US) in terms of doctoral studies. The study suggests that employers in developed countries are concerned that $\mathrm{PhD}$ graduates remain too narrowly focused and thus lack generic and transferrable skills. The research also indicates that doctoral degrees in the countries under study are considered research degrees, preparing PhD students for work in universities or research institutes.

However, Kehm's (2004) study also reveals that the academic labour market in some countriesfor example, Italy, Poland, and Romania - appears unattractive, compelling PhD graduates to seek employment outside academe but without the appropriate training (p. 296). Kehm's research emphasises the issue of transition to employment and suggests that the structure as well as the quality of doctoral studies in some European countries needs to be recontextualised so that the composition of their doctoral degrees encourages the acquisition of generic as well as transferrable skills (p. 294). In other words, the doctoral programmes need to be redesigned in line with labour-market demand, opening graduates' career prospects both inside and outside academe and achieving a balance between research and the professional orientation of $\mathrm{PhD}$ programmes.

Considering the importance of the inclusion of transferrable skills into doctoral studies, an empirical study was held at Imperial College in London (Walsh, Seldon, Hargreaves, Alpay, \& Morley, 2010). Approximately $1,000 \mathrm{PhD}$ students in the final stage of completing their thesis were surveyed. The findings are cited below to support the argument for the inclusion of transferable skills training into $\mathrm{PhD}$ programmes and, further, the argument that the assessment of $\mathrm{PhD}$ students should include skills training courses rather than the submission of dissertation papers alone (Walsh et al., 2010):

- Students possessing career aspirations expressed high levels of satisfaction after attending transferable skills training.

- Of the sample students, 63.4 per cent thought a range of transferable skills training was of great importance to their leadership qualities.

- Almost three-quarters (73 per cent) of the sample students had exceeded the mandatory attendance requirements, indicating the significance they placed on the transferable skills training programmes.

The next section provides a case study of the University of Bath, one of the leading universities in the UK. This is followed by a description of various PhD models adopted in the US and the UK that stipulate the attributes of academic PhDs as well as professional doctorates.

\section{The University of Bath: A Case Study}

The results of a case study of one of the leading private universities in the UK, the University of Bath, indicate that as producers of global as well as local knowledge, universities are crucial players in economic and social development (Naidoo \& Jamienson, 2007, p. 363). This study ob- 
served a gradual shift from the traditional university focus on 'mode 1 knowledge' to the new university focus on 'mode 2 knowledge'. The study uses the term 'mode 1 knowledge' to refer to linear, single-discipline knowledge, with the focus being on the production of knowledge. In contrast, 'mode 2 knowledge' is defined as knowledge that operates within a real problem-solving context. The study argues that although some universities in developed countries have already shifted from mode 1 to mode 2 knowledge, the $\mathrm{PhD}$ assessment processes at the University of Bath employ mode 1 knowledge, and that successful $\mathrm{PhD}$ candidates must have:

1. presented a thesis to the thesis committee that satisfies the board of examiners

2. made an original and significant contribution to knowledge

3. demonstrated evidence of originality of mind and critical judgment in a particular subject

4. presented material that is eligible to be published in peer-reviewed journals

5. demonstrated an understanding of the context of research that is appropriate for the subject of the thesis, particularly in the scientific, engineering, commercial and social contexts

6. passed a viva voce examination conducted by the board of examiners (Naidoo \& Jamienson, 2007, p. 369).

\section{PhD Model: US and UK}

Most doctoral programmes in the US are focused on developing the skills and knowledge required by an academic researcher (Gill \& Hoppe, 2009). However, according to this study, these skills and knowledge might not be directly applicable to practice. The research of Huisman and Naido (cited in Gill \& Hoppe, 2009, p. 29) illustrates this by summarising the doctoral programmes commonly implemented in developed countries. These are shown in Table 1.

\section{Table 1: Common Doctoral Programme Designs}

\begin{tabular}{ll}
\hline \multicolumn{1}{c}{ Name } & \multicolumn{1}{c}{ Description } \\
\hline Traditional PhD & - $\begin{array}{l}\text { dominated by the UK model, this doctorate emphasises the production } \\
\text { of a dissertation by PhD candidates under the supervision of one or } \\
\text { two faculty members }\end{array}$ \\
Taught Doctorate & - $\begin{array}{l}\text { less focus on coursework } \\
\text { dominated by the US model, coursework is given a considerable } \\
\text { amount of attention on top of the dissertation }\end{array}$ \\
Professional Doctor- & - $\begin{array}{l}\text { a newly designed doctorate that focuses on research as well as profes- } \\
\text { sional orientation so that doctoral candidates can apply their knowl- } \\
\text { ate }\end{array}$
\end{tabular}

Source: Adapted from Huisman \& Naido, 2006 (cited in Gill \& Hoppe, 2009, p. 29)

The empirical work of Bourner et al. (2001, cited in Gill \& Hoppe, 2009, p. 30) on the traditional $\mathrm{PhD}$ model identifies several distinct attributes that typify some notable shortcomings of this $\mathrm{PhD}$ model. Table 2 lists the attributes pertinent to the traditional $\mathrm{PhD}$ programmes practised particularly in the UK. 
Table 2: Research Doctorates

\begin{tabular}{ll}
\hline \multicolumn{1}{c}{ Attribute } & \multicolumn{1}{c}{ Academic PhD } \\
\hline 1. Career focus & Entry into academia \\
2. Domain of research topic & Disciplinary theory \\
3. Research type & Original investigation undertaken to gain new \\
& knowledge and understanding but not \\
& necessarily directed towards any practical aim \\
& or application \\
4. Intended learning outcomes & Contribution to the literature \\
5. Entry qualification and degree & Undergraduate degree with high marks \\
6. Integration of work/study & N/A \\
7. Integration of practice/theory & Low \\
8. Research outcomes & Long dissertation \\
9. Assessment & Dissertation-driven \\
10. Breadth & Narrow focus \\
\hline
\end{tabular}

Source: Adapted from Bourner et al., 2001 (cited in Gill \& Hoppe, 2009, p. 30)

In light of the issues recognised above, some criticisms of the academic $\mathrm{PhD}$ programmes in developed countries are cited below.

\section{Criticisms of the Traditional PhD Model}

Costley's (2013) research claims that international quality-assurance agencies have tended to prioritise the addition of work-related and practice-oriented assessment components to doctoral learning (p. 7). The research suggests that the traditional $\mathrm{PhD}$ model needs further modification to include postgraduate research training for employment and work. Kehm's (2004) study explains that the British Quality Assurance Agency (QAA) for higher education was established in 2001 with the aim of developing a framework for all degrees, including PhD programmes (p. 289). This research indicates that one of the fundamental tasks of the QAA is to ensure that students of all degrees, including doctoral studies, are able to demonstrate the required skills and competencies in order to be awarded their respective qualifications.

However, Burnham's investigation (cited in Morley, Leonard, \& David, 2003) into the UK's traditional method of $\mathrm{PhD}$ assessment finds that $\mathrm{PhD}$ assessment processes have escaped qualityassurance regulations. In particular, the study finds that viva voce examinations, used as one of the major means of assessing $\mathrm{PhD}$ candidates, are commonly used to humiliate examinees and to diminish the credibility of those who had examined (p. 5). In addition, Morley et al.'s (2003) study argues that the viva voce assessment followed by the traditional UK PhD model has no objective criteria and that the outcome depends entirely on the external examiner. Further, it was unclear how examiners were selected.

In contrast, the study conducted by Gill and Hoppe (2009) reflects the attractiveness of a doctoral degree in the US that relies completely on the content of the respective doctoral programmes. To address the shortfalls of the present PhD model in the US, the outcomes of this investigation recommend that the PhD programmes' approach to the learning and assessment practices should be more broad and multidisciplinary. In this case, the ultimate aim of the programme would not be a long dissertation; instead, project-oriented action research would be promoted.

Gilbert's investigation (cited in Walsh et al., 2010, p. 244) discusses further the introduction of skill-building training programmes into the curricula of doctoral degrees. Gilbert's investigation indicates that two views of research - including research as disciplinary stewardship and research as instrumental and entrepreneurial application - were suggested by researchers, but that most universities were under mounting pressure to conceptualise the second school of thought. 
Consistent with the discussions above, Freeman and Kochan (2012) surveyed a number of US university presidents on their perceptions of their academic doctoral preparation programmes. One of the main objectives of this study was to assist curriculum developers and faculty in higher education administration programmes to meet the needs of their doctoral students. The study found that presidents with a doctoral degree in higher education were better prepared to manage assessment as well as accountability of student learning in comparison to presidents with doctorates in other disciplines. The study emphasises the inclusion of diverse assignments using both oral and written communication formats with the purpose of addressing a diverse audience. Further, it underscores the importance of practical as well as industry-oriented assessments in the curricula of doctoral education programmes.

In Australia, the Department of Education, Science, and Training (DEST) undertook an extensive review of the quality of Australian universities' doctoral studies in 2002. The results of the review showed that doctoral education in Australia was under pressure to become more industry-oriented (Fink, 2006). Usher's research (cited in Fink, 2006) indicates that for the purpose of enlivening a knowledge society through building knowledge workers with performativity as well as capability, doctoral education should be multidisciplinary and industry-focused rather than traditional and academically driven (p. 37). Perry and Chavaya's study (cited in Fink, 2006) indicates that in Australia, while the Doctor of Business Administration (DBA) has been introduced alongside the traditional $\mathrm{PhD}$ model, with a view to adding coursework components, a few political issues have arisen (p. 41). The authors found evidence that instructions to supervisors and examiners for the $\mathrm{PhD}$ and DBA are the same, with the only exception being that the DBA thesis is to be guided by coursework. The same assessment criteria applied by the same examiner using largely the same instructions inevitably leads to a high degree of confusion between the $\mathrm{PhD}$ and the $\mathrm{DBA}$, as well as misunderstandings among the examiners.

The current practices and challenges of doctoral studies in developing countries are explored in the following section. This is followed by an in-depth discussion that highlights the learning and assessment practices of the existing PhD models of one developing country, Bangladesh. After this, a comparative analysis is undertaken of doctoral studies in developed and developing countries, in conjunction with learning and assessment practices.

\section{Doctoral Studies in Developing Countries}

The work of Rubdy, Tupas, Villareal, David, and Dumanig (2011) shows that the PhD models in developing countries are profoundly influenced by Western traditions, particularly in the provision of research and theoretical approaches (p. 64). For instance, the study indicates that Malaysia and Singapore are remarkably influenced by the traditional $\mathrm{PhD}$ models of the UK. In contrast, the work of Chen and Yeager (2011) indicates that Chinese higher education institutes are inherently influenced by the US models (p. 219).

Following is a brief description of the $\mathrm{PhD}$ programmes in three countries: China, Singapore, and Africa.

\section{China}

Research carried out by Cyranoski, Gilbert, Ledford, Nayar, and Yahia (2011) on the Chinese $\mathrm{PhD}$ model outlines a daunting scenario (p. 277). The study states that the number of $\mathrm{PhD}$ holders in China is skyrocketing (Cyranoski et al., p. 277). For example, in 2009 there were around 50,000 doctoral studies graduates in China. The study adds that with this strong enrolment growth, a persistent problem is the inferior quality of many $\mathrm{PhD}$ graduates. According to the study, poor curriculum, lack of quality-control mechanisms, $\mathrm{PhD}$ programmes that are too short in duration and less qualified supervisors are the major factors contributing to a generation of un- 
skilled PhD graduates (p. 277). However, Cyranoski et al. (2011) also reveal that the Chinese government has recently undertaken a major initiative in Chinese universities by introducing new thesis committees.

\section{Singapore}

Cyranoski et al.'s (2011) study indicates that enrolments in PhD programmes in a few developing countries have increased relatively rapidly, notwithstanding the fact that the quality of the $\mathrm{PhD}$ graduates is inconsistent (p. 276). The study illustrates that the enrolment of Singaporean nationals in $\mathrm{PhD}$ programmes has grown by 60 per cent in the past five years but that the quality of the $\mathrm{PhD}$ graduates remains in question. Meyer (2013) investigated doctoral studies in Singapore, the UK, and France, with particular emphasis on the curricula of the doctoral programmes of business administration and management. This investigation suggests that $\mathrm{PhD}$ programmes focus on report writing, academic presentations, and a six-month literature review. The study suggests that current assessment practices should emphasise those aspects that are highlighted by the real problems formulated by companies, institutions, or society at large; moreover, the assessments should be designed to require multidisciplinary solutions so that the graduates are assessed on their skills in critical thinking, critical problem solving, critical reading, and clear communication.

\section{Africa}

An analysis of African $\mathrm{PhD}$ programmes conducted by Negash, Anteneh, and Watson (2013) suggests that the most serious challenge facing many African countries today is the departure of $\mathrm{PhD}$ graduates from their universities (p. 272). While investigating the underlying reasons for this departure, the study uses the term 'brain drain' to refer to the migration of skilled professionals from low-income countries to high-income countries (p. 271). The study claims that two main factors are contributing to the escalation of the brain drain: 1) 'push factors' coming from lowincome countries and occurring particularly because of poor prospects for further training and lack of promotional opportunities; and 2) 'pull factors' coming from high-income countries that include prospects for further training and better remuneration. The research finds that the existing $\mathrm{PhD}$ programmes in African countries are dominated by the traditional $\mathrm{PhD}$ models of the UK and the US and suggests that African countries should focus on PhD dissertations that are fieldbased and solution-oriented so that more local talent can be cultivated to help slow the brain drain.

\section{Learning and Assessment Practices of Doctoral Studies in Bangladesh}

Potentially, Bangladesh is one of the emerging market economies of South Asia. Despite its large population of approximately 154.7 million people, the Millennium Development Goals Bangladesh Progress Report (2012) states that the country has achieved significant progress, particularly in areas such as poverty alleviation, primary school enrolment, and gender parity at primary-and secondary-level education. For instance, the study indicates that the incidence of poverty declined at an annual rate of 2.47 per cent between 1991 and 2010. The Millennium Development Goals Bangladesh Progress Report (2012) indicates that the education sector in Bangladesh faces substantial challenges in regard to achieving targets, including improving the quality of primary education and enhancing the quality of adult education in the areas of language and literacy. In contrast, the literature pertinent to higher education in Bangladesh reveals that the number of students completing higher education programmes is increasing exponentially. For example, according to Aminuzzaman's (2012) study, there were only seven public universities in Bangladesh in the 1980 s, but by 2013 the total number of public and private universities was 113 . While no single 
private university existed in the 1980s, by 2012 Bangladesh had 58 private universities with 200,000 students (Aminuzzaman, 2012).

\section{Enrolment Growth in Public Universities in Bangladesh}

Figure 1 summarises the total number of students enrolled in 31 public universities in 2009 and 2010, and in 34 public universities in 2011 (University Grant Commission of Bangladesh, 2011).

\section{Total Number of Students in Public Universities}

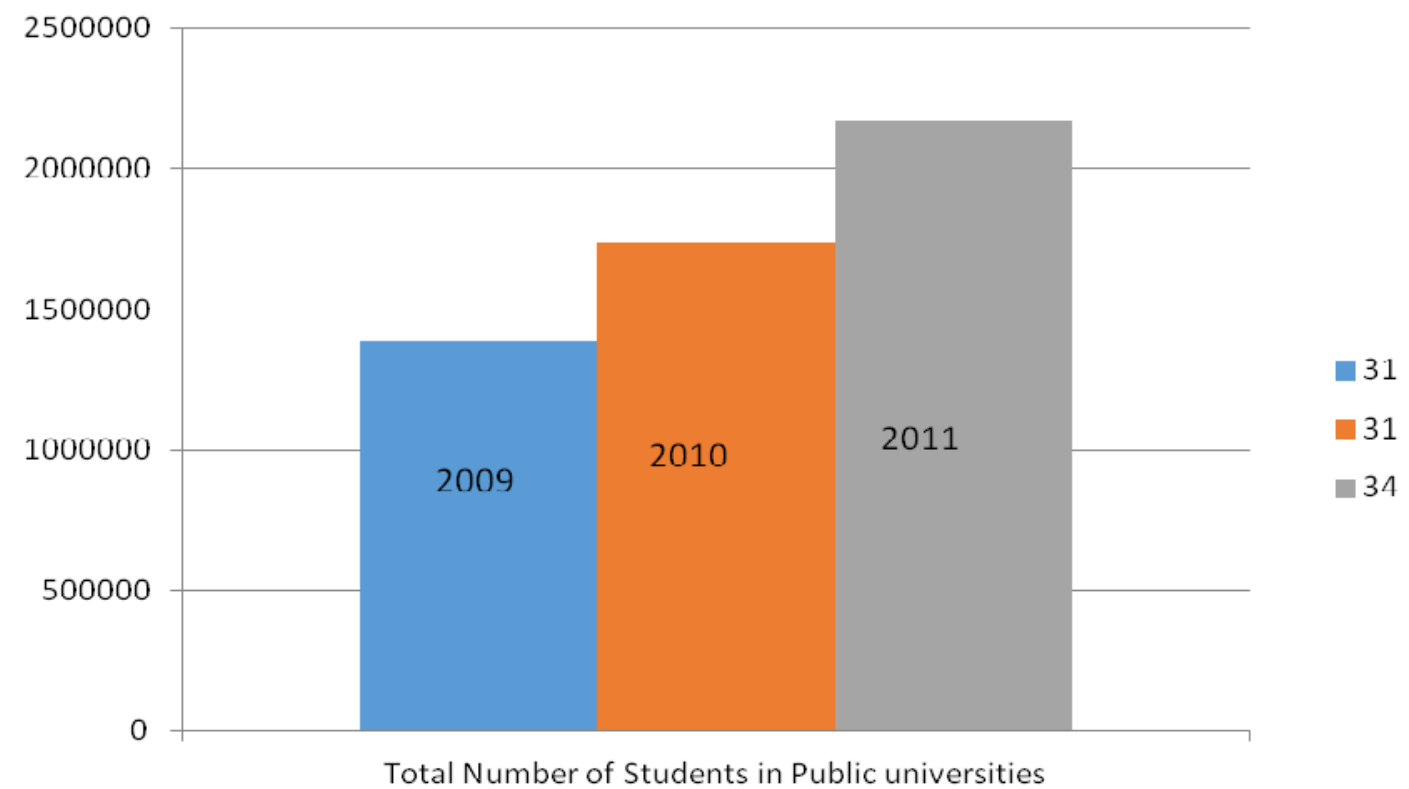

Figure 1: Total Number of Students in Public Universities in Bangladesh

\section{Discussion of Three Public Universities in Bangladesh}

For the purpose of discussing the learning and assessment practices of doctoral studies in Bangladesh, three public universities - the University of Dhaka (UOD), the Shahjalal University of Science and Technology (SUST), and the Bangladesh University of Professionals (BUP) - are examined in this paper. Recently, the Webometrics Ranking of World Universities (2013) conducted a study with the aim of determining the top-tier, middle-tier, and bottom-tier universities in Bangladesh. The research considers UOD a top-tier university, SUST a middle-tier university, and BUP a bottom-tier university. In conjunction with these tiers, the study ranks UOD as number 1, SUST as number 9, and BUP as number 45 among all the universities in Bangladesh.

The main reasons for selecting these three public universities for examination in this paper are:

1. the aim of this paper is to represent a generic model of the learning and assessment practices of $\mathrm{PhD}$ programmes that captures most of Bangladesh

2. in each of these universities, doctoral studies is one of the issues of concern

3. BUP has recently reformed its Master of Philosophy (MPhil) and PhD programmes, particularly in the area of assessment for $\mathrm{PhD}$ candidates. 
The next section provides a case study of these three public universities that illustrates the overall enrolment growth of higher education in general as well as the enrolment growth of MPhil and $\mathrm{PhD}$ studies in particular. In addition, it sheds light on the discussion regarding the current assessment practices of $\mathrm{PhD}$ programmes in the context of Bangladesh.

\section{University of Dhaka, Shahjalal University of Science and Technology, and Bangladesh University of Professionals: A Case Study}

\section{University of Dhaka}

Founded in 1921, UOD is one of the oldest public universities in Bangladesh. Today, it has 33,112 students and 1,805 teachers (University of Dhaka, n.d.). UOD has been immensely successful in producing millions of scholars and has been called 'the Oxford of the East' (University of Dhaka, n.d.).

\section{Shahjalal University of Science and Technology}

SUST, which specialises in science and technology, is one of the largest public universities in Asia. It has 15,314 students and 1,468 academic staff (SUST, n.d.). One of the striking features of SUST is its position among the top nine universities in Bangladesh in terms of providing $\mathrm{PhD}$ grants; hence, it characterises itself as a research-intensive university (SUST, n.d.).

\section{Bangladesh University of Professionals}

BUP emerged as Bangladesh's $29^{\text {th }}$ public university in 2008 with a unique focus on professionals, particularly those working in the defence sector (BUP, n.d.). To date, BUP has approximately 5,000 students. Although BUP is one of Bangladesh's brand new public universities, the number of students has grown substantially since 2008 as it has cemented its reputation as an institution offering a combination of research and practice.

Figure 2 summarises the total number of students enrolled in UOD, SUST and BUP in 2011.

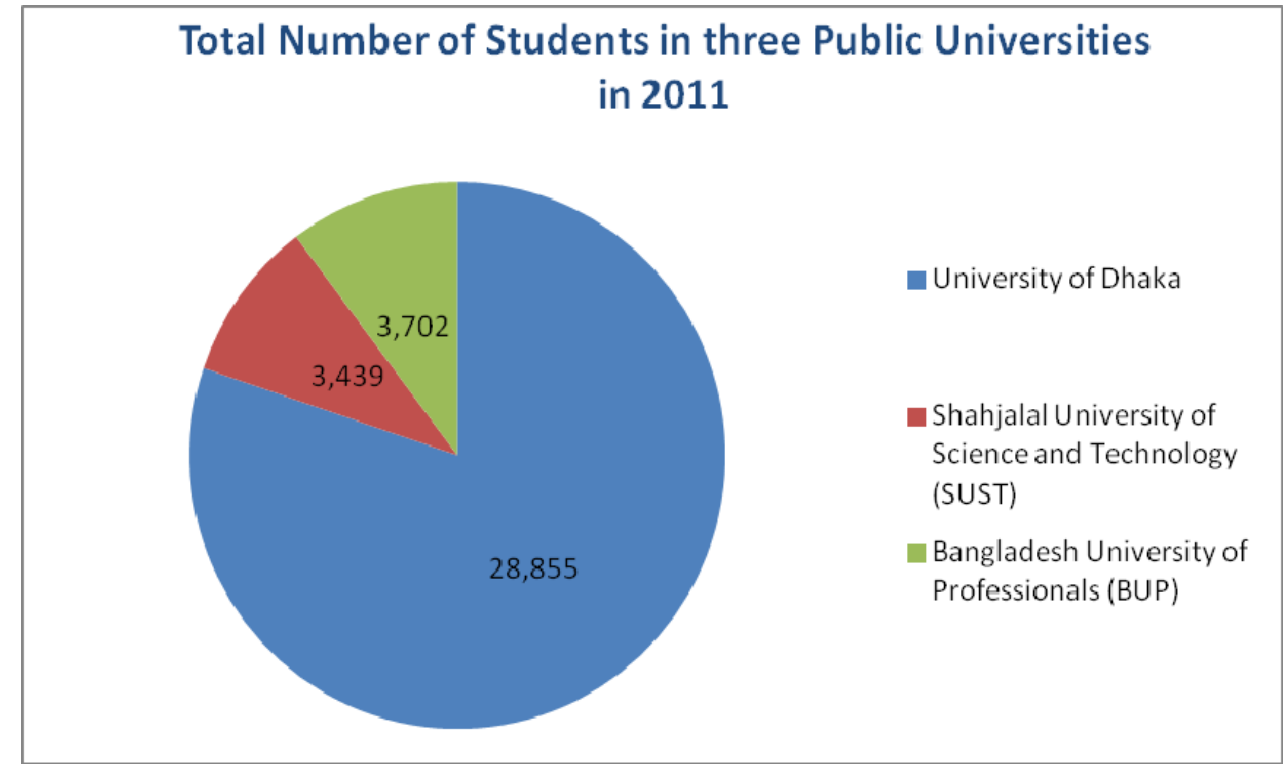

Figure 2: Total Number of Students in Three Public Universities in Bangladesh in 2011 Source: University Grant Commission of Bangladesh, 2011 


\section{Enrolment Growth of Doctoral Studies in UOD, SUST, and BUP}

Despite the strong heritage and long academic success of UOD, SUST, and BUP as researchintensive institutions, the recent enrolment growth of doctoral studies has been significantly low. Of the total number of students at UOD in $2011(28,855)$, only 490 were enrolled in MPhil or $\mathrm{PhD}$ programmes. Of the total number of students at SUST $(3,439)$ and BUP $(3,702)$ in 2011, only 27 new students were enrolled in MPhil or PhD programmes (University Grant Commission of Bangladesh, 2011) (see Figure 3).

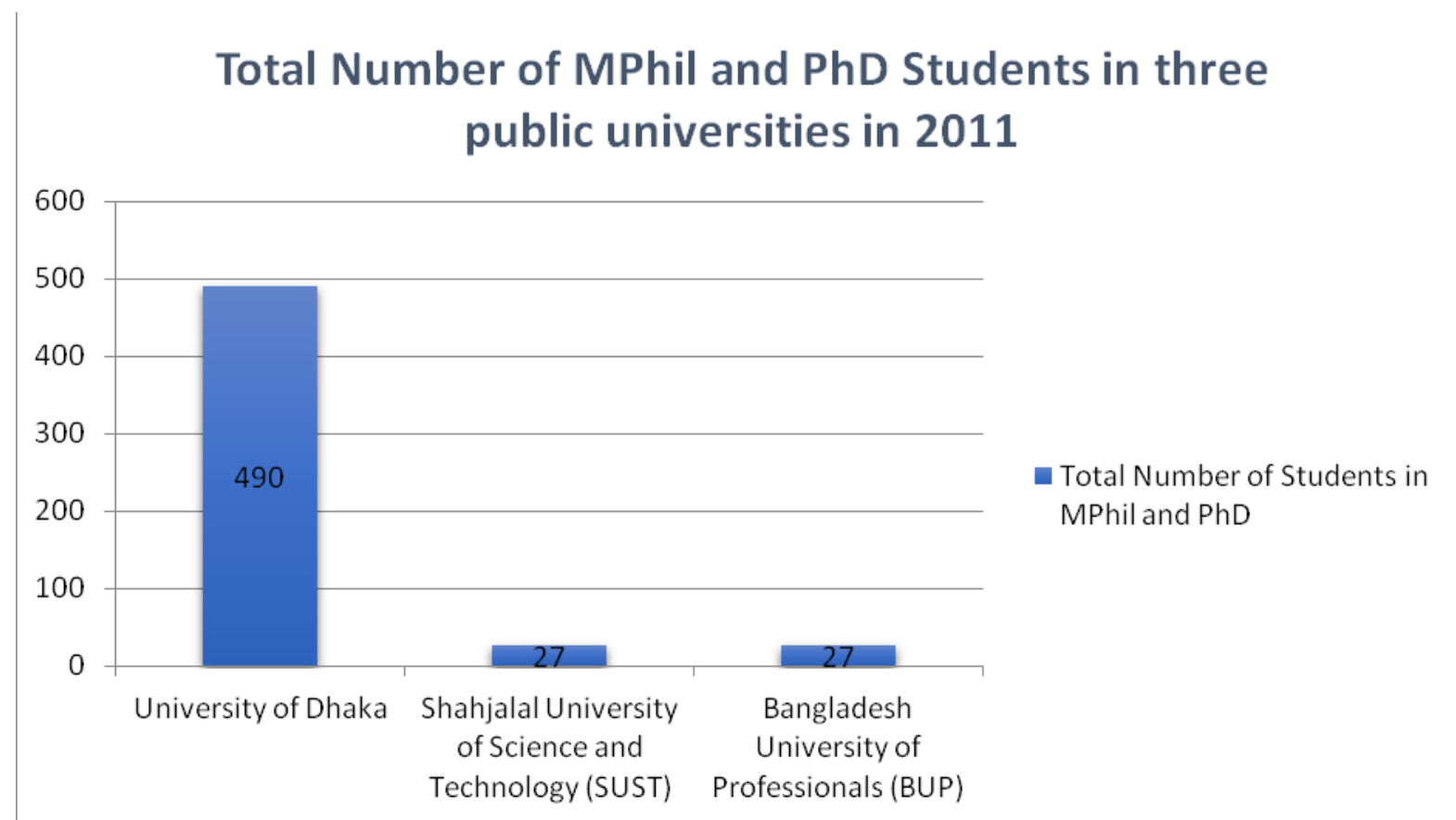

Figure 3: Total Number of MPhil and PhD Students in Three Public Universities in Bangladesh in 2011

Source: University Grant Commission of Bangladesh, 2011

\section{PhD Assessment Processes of UOD, SUST, and BUP}

The assessment processes used at UOD, SUST, and BUP are discussed in this section following an examination of these universities' institutional websites. UOD's website shows that entry into $\mathrm{PhD}$ programmes is subject to the student's previous qualifications as well as the publication of books or of journal articles in internationally recognised journals (UOD, n.d.). The minimum requirement for seeking admission into $\mathrm{PhD}$ programmes at UOD is either a MPhil or a Master of Science (MS). However, teachers with two years of teaching experience from colleges or universities are not required to meet this requirement.

In contrast, a student seeking admission to a PhD programme at SUST needs to fulfil one of any of the following requirements (SUST, n.d.):

- a Cumulative Grade Point Average (CGPA) of 3.25 out of 4.00 in bachelor programmes and a CGPA of 3.00 in master programmes

- two years of experience teaching at universities and at least one publication in recognised journals 
- three years of experience teaching at colleges and at least one publication in recognised journals

- three years of research experience working in reputable research organisations and at least three publications in standard journals.

At BUP, PhD candidates are selected according to their past academic record as well as a satisfactory performance in written and oral tests. For its PhD programmes, BUP prefers to admit teachers who are keen to develop their profession in research (BUP, n.d.).

In terms of the assessment processes for $\mathrm{PhD}$ programmes, a number of common practices are identifiable at UOD and SUST. An examination of the institutions' websites reveals that both of these universities follow the traditional PhD model (SUST, n.d.; UOD, n.d.). To elaborate, $\mathrm{PhD}$ candidates in both of these universities need to participate in at least one seminar per year, where they are required to present a topic of their research interest. In addition, $\mathrm{PhD}$ candidates at these two universities are assessed primarily on their dissertation paper and the presentation of their paper in the form of a viva voce examination.

In contrast, $\mathrm{PhD}$ candidates at BUP need to go through some points tests as follows (BUP, n.d.):

- Research Methodology and Quantitative Analysis (core subject): 100 points

- the completion of any two elective subjects from the list of optional courses: 200 points

- two seminar presentations: 100 points

- dissertation paper and viva voce examination: 100 points.

Although BUP differs from UOD and SUST in terms of the assessment of $\mathrm{PhD}$ students, and notwithstanding its focus on professionals, its admission processes encourage teachers and researchers to enrol in PhD programmes.

Although both UOD and SUST promote themselves as research-based universities, the data pertinent to enrolment growth in PhD programmes is not encouraging. Hull's 1943 theory of learning and motivation (cited in Patria, 2012) argues that the learner is not simply pushed into action by 'drive', but that they are also pulled by 'incentives' (p. 186). Moreover, research indicates that learners' readiness to learn becomes greater when they consider learning to be of great value, when their need to learn is clear, and when their ability to learn is well-supported within the context of a knowledge-intensive society (James, 2011).

It is evident that each of the three universities studied in this paper needs to redesign its present assessment practices so that newly designed learning and assessment practices can eventually act as incentives to transform $\mathrm{PhD}$ candidates' existing knowledge and skills, preparing them not only to be skilled researchers but also skilled practitioners. However, more research needs to be conducted prior to redesigning the assessment practices.

\section{Doctoral Studies in Developed and Developing Countries: A Comparative Analysis}

While the literature finds many similarities and differences in the learning and assessment practices of doctoral studies in developed and developing countries, the studies share the same recommendation - that the existing $\mathrm{PhD}$ models be redesigned. The literature pertinent to doctoral studies in developed countries provides considerable discussion on the current shortcomings of doctoral studies, particularly in terms of the structure and content of the programmes. However, these issues are not among the focuses of the literature regarding Bangladesh. In the higher education institutes of developing countries, discussion of the new professional doctorates is not yet 
as common as in developed countries. Regarding the admission requirements for $\mathrm{PhD}$ programmes, the qualifying indicators commonly applied in developed countries include the Graduate Record Exam (GRE) and undergraduate degrees with honours. In contrast, developing countries emphasise the results of an admission examination (comprising oral and written tests), having previous academic qualifications (in particular, a MPhil or a MS), and having published in standard journals. In both developed and developing countries, $\mathrm{PhD}$ assessment is largely dissertation-driven, notwithstanding the US and UK literature on the doctoral programme design remain to be active whereas this practice is largely absent from the literature of developing countries.

\section{Theoretical Framework}

This section will discuss four different theories that contribute to the identification of the factors that lead to the production of skilled and knowledgeable $\mathrm{PhD}$ graduates. These theories are: 1) Bozeman et al.'s (2001) theory of social and technical human capital; 2) Levine's (2007) ninepoint template; 3) Lovitts's (2005) study; and 4) Leech's (2012) model. The discussion of these theories makes several notable contributions to the literature.

\section{Bozeman et al.'s (2001) Theory of Social and Technical Human Capital}

Bozeman et al.'s (2001) theory focuses primarily on two attributes - human capital and social capital — required by a PhD candidate to be a successful researcher. The researchers use the term 'human capital' to refer to an individual's cognitive skills, knowledge, and craft skills. Bourdieu and Wacquant (1992) define the term 'social capital' as the sum of the actual and virtual resources that can be accrued by an individual by either establishing a durable network or possessing institutionalised relationships of mutual recognition. The theory of social and technical human capital stipulates that prior to becoming a successful researcher, PhD students are assessed on their human capital on the basis of their level of participation in the projects. Thus, the success of $\mathrm{PhD}$ students depends on the extent of the human capital they obtain (Leech, 2012, p. 20). A limitation of this model is that it does not emphasise the curriculum (see Figure 4); as a consequence, it might be difficult to define best practice in line with assessing a $\mathrm{PhD}$ candidate's knowledge and skills.

\section{Levine's (2007) Nine-point Template}

This theory encapsulates nine areas as success indicators against which the quality of $\mathrm{PhD}$ programmes are assessed. The nine areas are: 1) purpose, 2) finance, 3) faculty, 4) research, 5) curriculum coherence, 6) curriculum balance, 7) admissions, 8) graduate and degree standards, and 9) assessment (see Figure 4). Typically, these nine areas determine whether the $\mathrm{PhD}$ programme is classified as exemplary or inadequate (Levine, 2007, p. 16). Thus, one of the major strengths of this model is its quality-control mechanism. The main problem with this model is that it does not have any components that might highlight the individual resources of $\mathrm{PhD}$ students (see Figure 4), rendering the model potentially paradoxical. For example, the nine points provide a basis on which a PhD programme can be assessed, but any corrective actions in relation to the thinking style, personality, and intelligence of an individual $\mathrm{PhD}$ candidate are apparently missing. As a result, in terms of benefitting PhD candidates, the adoption of this model may be moderately worthwhile. 


\section{Lovitts's (2005) Study}

This theory suggests three layers highlighting three aspects that eventually lead doctoral students to produce outstanding research and scholarship (Lovitts, 2005, p. 139): 1) individual resources, 2) micro-environment, and 3 ) macro-environment (see Figure 4). According to this theory, these three aspects ultimately act as determinants of whether a $\mathrm{PhD}$ candidate completes his or her dissertation on time. Therefore, one of the key focuses of this model is completion as well as creative performance. One of the key strengths of this model is the inclusion of the culture of graduate education and the culture of discipline under the 'macro-environment' layer. One of the major limitations of the model is its core focus - that is, completion and creative performance-because although the model emphasises the production of outstanding research and scholarship, a focus on the production of skilled and knowledgeable researchers is absent.

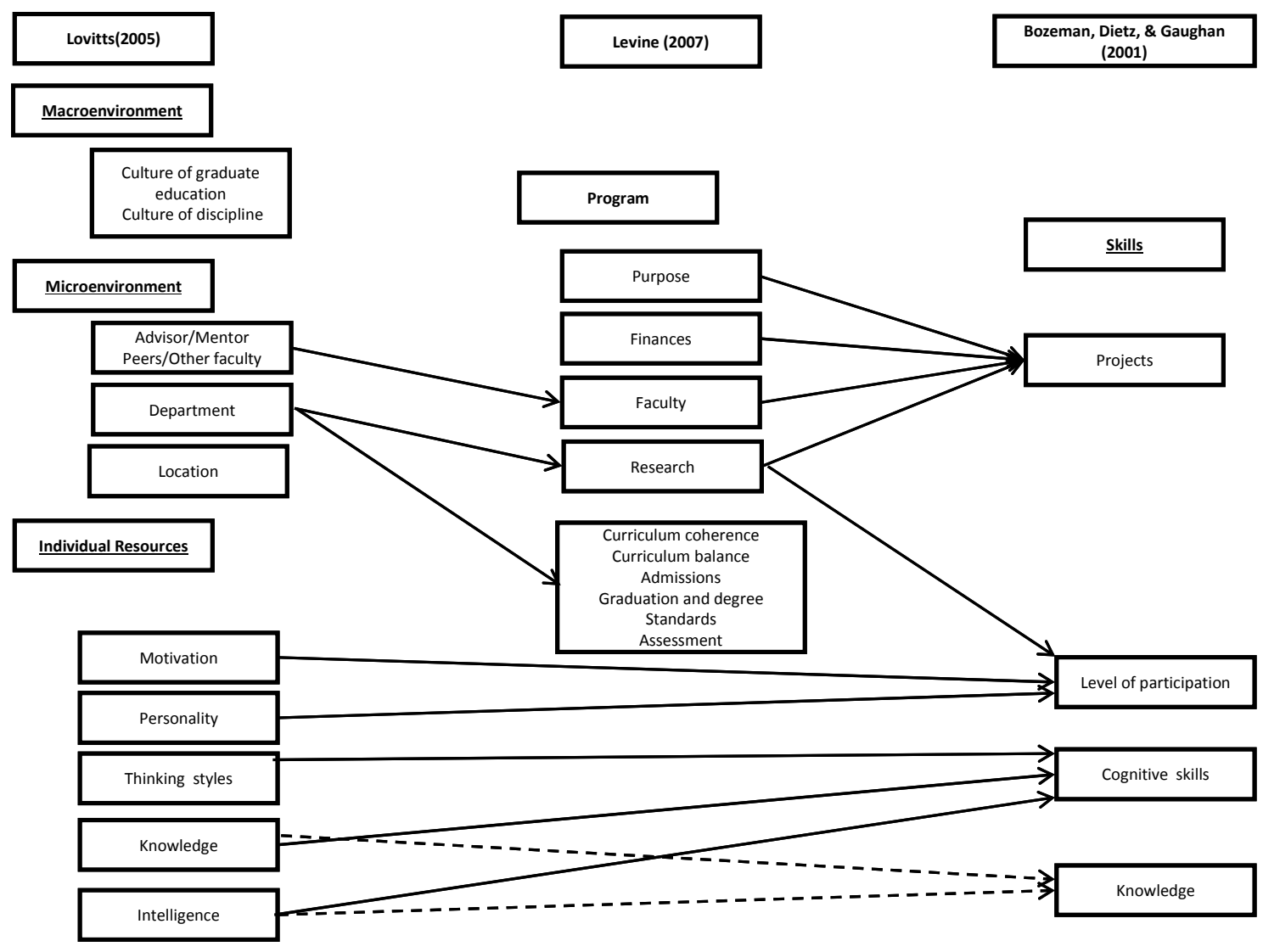

Figure 4: Comparison of the Three Theories

Source: Leech, 2012, p. 24

\section{Leech's (2012) Model}

Leech's new model (2012, p. 32) is largely a modification of Bozeman et al.'s (2001) theory of social and technical human capital, Levine's (2007) nine-point template, and Lovitts's (2005) study. The major strength of Leech's (2012) model is that it incorporates the important factors from the three other theories while placing greater emphasis on producing skilled and knowledgeable researchers (see Figure 5). 


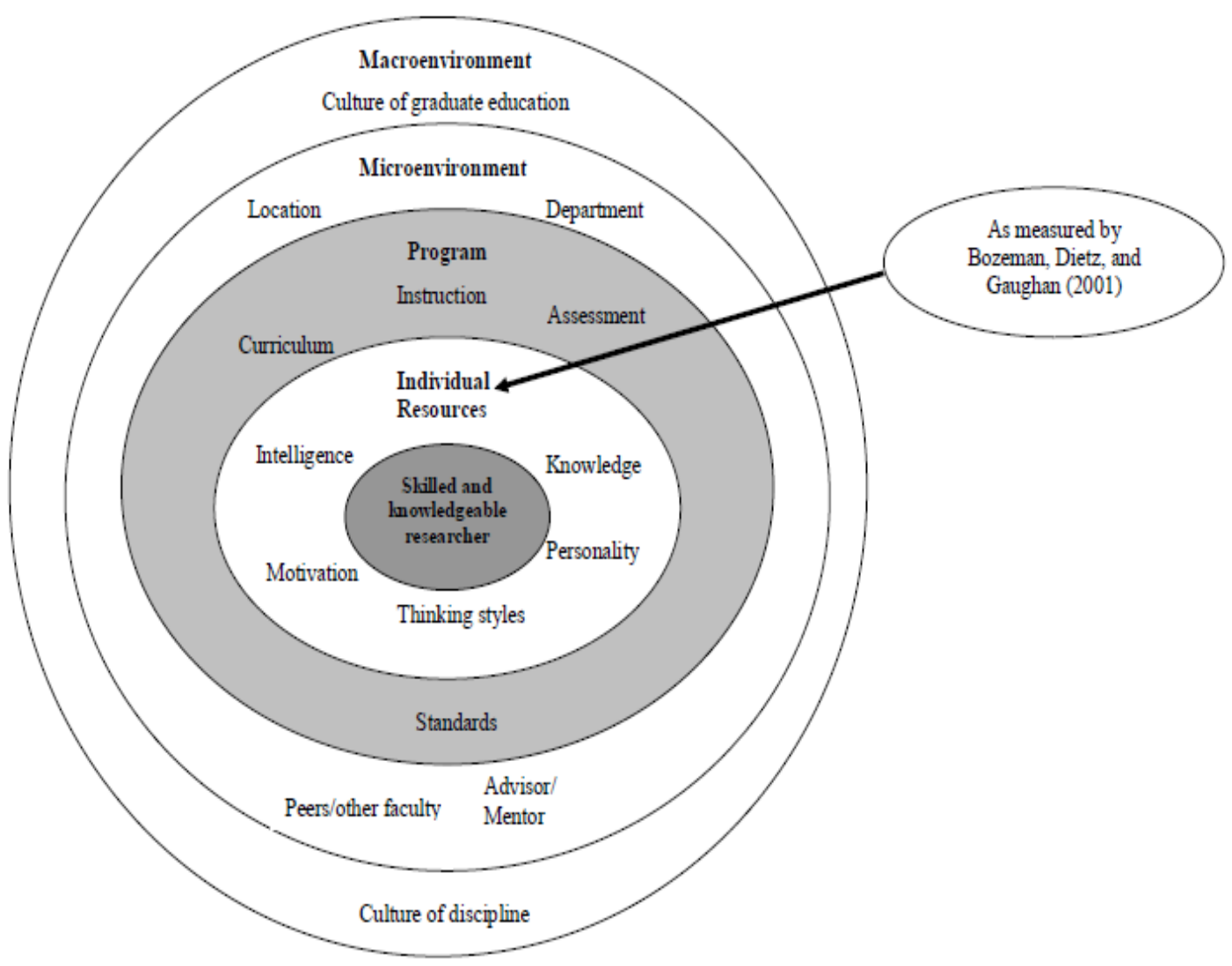

Figure 5: New model for developing skilled and knowledgeable researchers Source: Leech, 2012, p. 32

Although the preceding discussion reveals the importance of introducing industry-driven assessments to produce skilled and knowledgeable researchers, Leech's (2012) study on the theories of Levine (2007), Lovitts (2005), and Bozeman et al. (2001), and finally her own model, does not address in particular the processes of designing and implementing new learning and assessment practices for doctoral studies. Future studies will need to conduct this practical work.

\section{Implications of the Study}

Education and development are interlinked. By utilising the R\&D activities of higher education institutes, a country can propel itself into a position as a centre of productive human resources, irrespective of its population density (Andaleeb, 2003). Regarding the R\&D systems of developing countries, it is important to note a research finding that claims that in most cases, there is more research than development in the R\&D activities of these countries (Ellis, Fernández, \& Pathirage, 2009, p. 176). According to Ellis et al.'s (2009) study, this trend is evident mainly in the government and higher education sectors of developing countries. So far in Bangladesh, there has been little discussion about the reformation of the present learning and assessment processes for doctoral studies. In fact, far too little attention has been paid to enhancing the skills and knowledge of PhD students to ensure that they are well prepared for working both in and outside of academe.

To support this claim, the University Grant Commission of Bangladesh (UGC) conducted a survey of four renowned public universities and 250 teachers. The universities surveyed were UOD, 
Khulna University, Rajshahi University, and Bangladesh Agricultural University (Billah, 2011). The research findings reveal that around 13 per cent of university teachers are not at all concerned about conducting research. Although 20 per cent of the teachers are trying to perform well in research publications, the poor infrastructure of their R\&D activities means that these publications seldom reach the global standard. Consistent with these findings, another study shows that as a potential human-resource export country, Bangladesh might not capture the regional as well as the global employment opportunities unless it invests in developing a context- and contentrelevant set of criteria to assess research components in higher education programmes (Aminuzzaman, 2012).

In response to such an urgent call to re-evaluate and redesign various research programmes - in particular, doctoral studies - the Bangladeshi government has recently allowed a private monitoring body, the Education Quality Assurance Foundation (EQAF) to establish a quality-assurance mechanism for higher education institutions (Billah, 2012). However, EQAF's venture has been conducted with an emphasis on minimum standards, facilities, and support structure for private universities. Needless to say, no research has been found that surveys the current doctoral programme design as well as its associated stakeholders, especially in the light of the present learning and assessment practices for doctoral degrees. This discussion paper will serve as a basis for future research, particularly in the areas of learning and assessment processes for doctoral studies in Bangladesh. Consistent with this discussion, any empirical work will make several noteworthy contributions to assisting $\mathrm{PhD}$ examiners, supervisors, students, and related stakeholders to base their processes on best practice against a multidisciplinary, skill-based, and industry-driven learning and assessment system.

A survey conducted by the Bangladesh Bureau of Statistics shows that the total profit from 31 private universities in 2009 was approximately AUD50 million; however, the research expenditure of these universities in the same year was only approximately AUD2.53 million (Billah, 2012). Another significant observation from the institutional websites of all private universities is that none of the private universities is yet offering doctoral studies to their students, even though there are around 200,000 students studying in these universities, which as a whole are economically strong and viable. Therefore, the literature review of doctoral studies in developed and developing countries also offers insights into the entrepreneurial application of the design of $\mathrm{PhD}$ programmes, and hence the chance to provide the stakeholders of private universities in Bangladesh with a basis on which any future research might be undertaken. Finally, the outcomes of this discussion paper make some noteworthy contributions to the current literature regarding the learning and assessment practices of doctoral studies; these research findings can be applied elsewhere in the world.

\section{Recommendations}

Following a discussion of the extant literature as well as the theories in relation to the learning and assessment practices of doctoral studies in Bangladesh, some recommendations are provided that suggest further investigation:

- In practical terms, the present learning and assessment processes of doctoral studies in Bangladesh need to be redesigned, with a research emphasis on not only filling the gap in the literature but also identifying problems in practice.

- The learning and assessment curriculum needs to be redesigned so that it is more broad and multidisciplinary.

- Training needs to be facilitated for PhD supervisors so that they can prepare assignments that fit internationalised curricula and so that the programme encourages international students to undertake their $\mathrm{PhD}$ in Bangladesh. In this way, $\mathrm{PhD}$ graduates of Bangla- 
deshi universities will be able to take advantage of the diversity that will ultimately prepare them to share their knowledge globally. Nakar (2013) indicates that with more diverse cultures, more internationalised curricula are required to acknowledge this diversity (p. 80).

- The curriculum of the $\mathrm{PhD}$ programmes in Bangladeshi universities needs to be recontextualised by including diverse assignments and action-based case studies. Rehm (2008) suggests that teachers with a disposition of openness will be more likely to use the strategies that comprise diverse approaches to meet common goals, thus enabling students to flourish.

\section{Conclusion}

Utilising the talents and potential of skilled and knowledgeable researchers appears pivotal for any country in the world to build a knowledge-intensive society. The globalisation of doctoral education has opened the door to scholars who have the capability to contribute to the world in general and to enliven their respective countries through their research-based knowledge and practice-based skills. In this light, the above discussion - particularly regarding the learning and assessment practices of doctoral programmes in Bangladesh — remains to be distinctive.

\section{References}

Aminuzzaman, S. M. (2012). Quality issues of higher education Bangladesh. Retrieved from http://www.bdeduarticle.com/tertiary-education

Andaleeb, S. S. (2003). Revitalizing higher education in Bangladesh: Insights from alumni and policy prescriptions. Higher Education Policy, 16(4), 487-504.

Billah, M. (2011). UGC reveals poor performance of public universities. Retrieved from http://www.bdeduarticle.com/tertiary-education

Billah, M. (2012). Research and our universities. Retrieved from http://www.bdeduarticle.com/tertiaryeducation

BUP. (n.d.). Bangladesh University of Professionals. Retrieved from http://www.bup.edu.bd/

Bourdieu, P., \& Wacquant, L. J. D. (1992). An invitation to reflexive sociology. Chicago, IL: University of Chicago Press.

Bozeman, B., Dietz, J. S., \& Gaughan, M. (2001). Scientific and technical human capital: An alternative model for research evaluation. International Journal of Technology Management, 22(7-8), 716-740.

Chen, Q., \& Yeager, J. L. (2011). Comparative study of faculty evaluation of teaching practice between Chinese and U.S. institutions of higher education. Frontiers of Education in China, 6(2), 200-226.

Costley, C. (2013). Evaluation of the current status and knowledge contributions of professional doctorates. Quality in Higher Education, 19(1), 7-27. doi:10.1080/13538322.2013.772465

Cyranoski, D, Gilbert, N, Ledford, H, Nayar, A \& Yahia, M. (2011). Education: The PHD factory. Nature, $472,277-279$.

Ellis, S., Polcuch, E. F., \& Pathirage, R. (2009). Measuring R\&D in developing countries: International comparability and policy relevance. In V. L. Meek, U. Teichler, \& M. L. Kearney, Higher education, research and innovation: Changing dynamics, 172-186. Available at http://www.oei.es/pdf2/183071E.pdf\#page=175

Freeman, S., Jr., \& Kochan, F. K. (2012). Academic pathways to university leadership: Presidents' description of their doctoral education. International Journal of Doctoral Studies, 7, 93-124. Retrieved from http://ijds.org/Volume7/IJDSv7p093-124Freeman353.pdf 
Fink, D. (2006). The professional doctorate: Its relativity to the Ph.D. and relevance for the knowledge economy. International Journal of Doctoral Studies, 1, 35-44. Retrieved from http://www.ijds.org/Volume1/IJDSv1p035-044Fink14.pdf

Gill, T. G. \& Hoppe, U. (2009). The business professional doctorate as an informing channel. International Journal of Doctoral Studies, 4, 27-57. Retrieved from http://www.ijds.org/Volume4/IJDSv4p027057Gill267.pdf

James, D. (2011). Principles of vocational, technical and adult education. Retrieved from http://djames84.net/Cert 51/VTAE\%20Class\%20Booklet\%20Weekend\%20Class.pdf

Jones, M. (2013). Issues in doctoral studies- Forty years of discussion: Where have we been and where are we going? International Journal of Doctoral Studies, 8, 83-104. Retrieved from http://ijds.org/Volume8/IJDSv8p083-104JonesFT129.pdf

Kehm, B. M. (2004). Developing doctoral degrees and qualifications in Europe: Good practice and issues of concern-A comparative analysis. In D. Lincoln (Ed.), Studies on higher education (pp. 279-298).

Leech, N. L. (2012). Educating knowledgeable and skilled researchers in doctoral programs in schools of education: A new model. International Journal of Doctoral Studies, 7, 19-37. Retrieved from http://ijds.org/Volume7/IJDSv7p019-037Leech325.pdf

Levine, A. (2007). Educating researchers. Washington, DC: The Education Schools Project. 16.

Lovitts, B. E. (2005). Being a good course-taker is not enough: A theoretical perspective on the transition to independent research. Studies in Higher Education, 30(2), 137-154.

Maclean, R. \& Wilson, D.N., (2009). Education for the changing world of work: Developing skills for the new economy. UNESCO-UNIVOC. Retrieved from http://www.unevoc.unesco.org/72.html?\&tx_drwiki_pi1\%5Bkeyword\%5D=UNEVOC+International + Handbook+on+TVET

Meyer, A. D. (2013). The future of doctoral education in business administration. Journal of Management Development, 32(5), 477-486.

Millennium Development Goals Bangladesh Progress Report. (2012). Retrieved from http://www.undp.org/content/dam/bangladesh/docs/MDG/2012\%20Report\%20MDG.pdf

Morley, L., Leonard, D., \& David, M. (2003). Quality and equality in British PhD assessment. Quality Assurance in Education, 11(2), 64-72.

Negash, S., Anteneh, S., \& Watson, R. T. (2013). A PhD in information systems for emerging economies: The Addis Ababa University Model. Information Technology for Development, 18(3), 270-276. doi:10.1080/02681102.2011.604081

Naidoo, R., \& Jamieson, I. (2007). University positioning and changing patterns of doctoral study: The case of the University of Bath. European Journal of Education, 42(3), 363-373.

Nakar, S. (2013). Understanding VET teachers' challenges in providing quality education to international students. International Journal of Training Research, 11(1), 79-88.

Patria, B. (2012). Change management in the higher education context: A case of student-centred learning implementation. International Journal of Education, 4(4), 176-191. doi:10.5296/ije.v4i4.2515

Rubdy, R., Tupas, R, F., Villareal, C. D., David, M. K., \& Dumanig, F. P. (2011). Review of doctoral research in English language education in the Philippines, Singapore and Malaysia (2007-2010). Language Teaching, 45(1), 64-88.

Rehm, M. L. (2008). Careers and technical education teachers' perceptions of culturally diverse classes: Rewards, difficulties, and useful teaching strategies. Career and Technical Education Research, 33(1), 45-64.

SUST. (n.d.). Shahjalal University of Science and Technology. Retrieved from http://www.sust.edu/ 
Tovey, M. D., \& Lawlor, D. R. (2008). Training in Australia. Franchise Forest, NSW: Pearson Education Australia.

University Grant Commission of Bangladesh. (2011). Annual Report. Bangladesh: The Government Republic of Bangladesh. Retrieved from http://www.ugc.gov.bd/reports/Part-2.doc

University of Dhaka. (n.d.). Retrieved from http://www.univdhaka.edu

Walsh, E., Seldon, P., Hargreaves, C., Alpay, E., \& Morley, B. (2010). Evaluation of a program of transferable skills development within the PhD: Views of late stage students. International Journal for Researcher Development, 1(3), 223-247.

Webometrics Ranking of World Universities. (2013). Retrieved from http://www.webometrics.info/en/asia/bangladesh $\% 20$

\section{Biography}

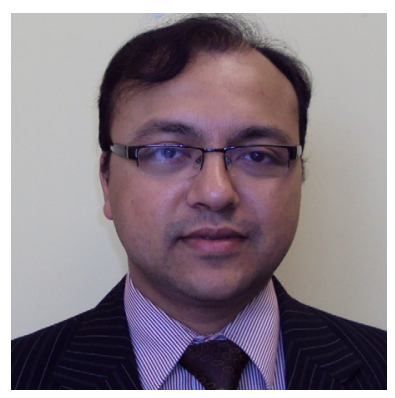

Ahabab Chowdhury (MBA, BBA) is currently pursuing PhD in Management at the University of Wollongong. Ahabab has been holding various senior management and teaching positions, in the areas of general management, strategic management, human resource management, educational management and vocational education and training. Ahabab is currently serving as Associate Editor for the International Journal of Doctoral Studies (IJDS). In addition, Ahabab is working as Casual Academic Teacher at the University of Wollongong. Ahabab was awarded as a World-Class Manager and received a Grand Champion Certificate during an event of the Global Business Strategy Game in 2006; organized by the University of Technology Sydney (UTS) and the University of Alabama, USA. Throughout his career, Ahabab has been very successful to encourage his team to work in a harmonious and collaborative environment where all work as partners with the common goal of providing the best education and support to students so they achieve their highest potentials in all areas. 